\title{
SISTEM INFORMASI UMPAN BALIK PROSES BELAJAR MENGAJAR TERHADAP STAF PENGAJAR BERBASIS WEB PADA JURUSAN TEKNOLOGI INFORMASI POLITEKNIK NEGERI PADANG
}

\author{
Oleh : \\ Yulherniwati, Rasyidah, Ronal Hadi', Rika Idmayanti \\ Jurusan Teknologi Informasi Politeknik Negeri Padang \\ ronalhadi@yahoo.com
}

\begin{abstract}
ABSTRACK
Feedback Information System Teaching and Learning Against Web-Based Teaching Staff In the Department of Information Technology Padang State Polytechnic is an information system that receives feedback from the learning process of students to teaching staff in the form of questionnaires, to then process and provide the necessary information. This system can be accessed by many users at the same time. Users of this system consists of students, operators, administrator, and faculty leaders. The system is built using PHP programming language and MySQL database server.

This system could make it easier, save time and reduce errors in entering, process and provide information on the results of data processing questionnaires. While limitations are only limited to faculty assessment only and limited to the processing of assessment ratio.
\end{abstract}

Keywords : System Information, Feedback Teaching and Learning, Web, PHP, MySQL Server

\section{PENDAHULUAN}

Politeknik Negeri Padang (PNP) menerapkan sistem umpan balik Proses Belajar Mengajar (PBM) oleh mahasiswa terhadap staf pengajar. Hal ini dilakukan oleh setiap jurusan termasuk Jurusan Teknologi Informasi setiap akhir semester melalui penyebaran kuesioner. Kuesioner yang digunakan merupakan kuesioner yang telah ditetapkan oleh Satuan Penjamain Mutu (SPM) Politeknik Negeri Padang. Kuesioner terdiri dari 29 pertanyaan yang dikelompokkan dalam beberapa kelompok pertanyaan. Mahasiswa diminta memberikan jawaban meliputi tingkat kepentingan dari setiap kondisi yang dtanyakan (yaitu: Sangat Penting,
Penting, Biasa, Tidak Penting, Sangat Tidak Penting) serta penilaian terhadap kondisi yang ditanyakan tersebut (Sangat Baik, Baik, Cukup, Kurang, Buruk). Hasil kuesioner dijadikan bahan kajian bagi peningkatan PBM semester selanjutnya.

Pada sistem yang berjalan selama ini kuesioner masih menggunakan kertas. Kuesioner dibagikan untuk diisi mahasiswa pada saat Ujian Akhir Semester (UAS) dan dikumpulkan kembali, disimpan untuk kemudian diolah. Jumlah responden dibatasi 10 orang per kelas per matakuliah yang dipilih secara acak sehingga didapatkan data sampel. Kelemahan sistem saat ini adalah : pengisian kuesioner yang 
dilakukan pada saat Ujian Akhir Semester (UAS) dapat mengurangi waktu mahasiswa mengerjakan ujian, penginputan membutuhkan waktu yang lama dan tenaga kerja yang banyak, pengolahan data membutuhkan waktu yang lama dan tingkat kesalahan yang relatif tinggi, banyak menggunakan kertas dan membutuhkan tempat penyimpanan untuk kertas isian kuesioner.

Perkembangan teknologi yang semakin pesat, khususnya teknologi informasi dan telekomunikasi berperan penting dalam memberikan kemudahan dan fasilitas yang mendukung manusia dalam menyelesaikan tugas-tugasnya. Teknologi komputer merupakan salah satu teknologi yang mewarnai sebagian besar kehidupan manusia saat ini. Dunia pendidikan, perkantoran, industri telekomunikasi, kalangan bisnis, pariwisata, hiburan dan militer telah menggunakan teknologi komputer sebagai alat bantunya.

Pertumbuhan web juga sudah semakin pesat dengan tingkat akses yang tinggi. Terkoneksinya seluruh mahasiswa Jurusan Teknologi Informasi ke internet dan meningkatnya fasilitas akses internet di PNP dari segi kecepatan dan keamanan memungkinkan adanya komunikasi antara mahasiswa dengan jurusan dengan lebih mudah. Oleh sebab itu, web dapat dimanfaatkan untuk sistem umpan balik bagi mahasiswa yaitu dalam hal menilai Proses Belajar Mengajar (PBM) terhadap staf pengajar, menghimpun dan mengolah data serta melakukan analisis dan pelaporan yang diperlukan.

Terdapat beberapa penelitian menyangkut pembangunan sistem berbasis web untuk umpan balik mahasiswa terhadap PBM melalui kuesioner perkuliahan di sejumlah perguruan tinggi. Di antaranya penelitian yang dilakukan Andri Heryandi (2012) yang membantu dalam penyelesaian masalah lamanya penginputan kuesioner dan kekurangakuratan dalam pemasukan data. Namun penelitian ini belum menghasilkan output pengolahan kuesioner. Pilihan jawaban merupakan penilaian mahasiswa terhadap dosen atas butir-butir pertanyaan yang diberikan. Jawaban terdiri dari 5 pilihan yaitu Sangat Baik, Baik, Cukup, Kurang dan Sangat Kurang. Sedangkan dalam penelitian oleh Sri Hartini dkk (2010), penilaian proses belajar mengajar tergabung dalam Sistem Evaluasi Kinerja Institusi Pendidikan, di dalamnya juga menggunakan pilihan jawaban kualitatif. Kedua penelitian tersebut tidak menanyakan tingkat kepentingan dari kondisi yang ditanyakan.

Beradasarkan hal-hal yang telah dipaparkan, penelitian ini akan membahas permasalahan yaitu Bagaimana merancang dan membangun sistem informasi berbasis web untuk umpan balik PBM terhadap staf pengajar menurut format dan cara pengolahan yang berlaku di PNP, agar :

1. Pengisian kuesioner tidak dilakukan pada saat Ujian Akhir Semester (UAS) sehingga tidak mengurangi waktu mahasiswa dalam mengerjakan soal-soal ujian

2. Pengolahan data tidak membutuhkan waktu yang lama dan mengurangi tingkat kesalahan

3. Tidak banyak menggunakan kertas sehingga tidak membutuhkan tempat penyimpanan untuk kertas isian kuesioner

4. Informasi tersedia dengan mudah dan cepat bagi pimpinan maupun pihakpihak yang mendapat umpan balik 
Tujuan Penelitian adalah untuk menghasilkan sistem informasi umpan balik proses belajar mengajar terhadap staf pengajar yang dapat :

1. Memudahkan, menghemat waktu dan mengurangi tingkat kesalahan dalam memasukkan dan mengolah data kuesioner.

2. Menyediakan informasi tentang hasil analisis umpan balik / kuesioner, kepada pimpinan untuk kemudian dapat ditindaklanjuti dan kepada staf pengajar yang menjadi objek penilaian untuk dijadikan bahan koreksi jika terdapat kekurangankekurangan dalam mengajar sehingga mutu kegiatan belajar mengajar dapat ditingkatkan.

\section{METODE PENELITIAN}

\section{Studi Pustaka}

Studi Pustaka dilakukan untuk mengumpulkan dan mempelajari referensi dan teori-teori pendukung yang berkaitan dengan aplikasi yang akan dibangun.

\section{Analisis Kebutuhan}

Analisis kebutuhan untuk mengetahui kebutuhan fungsional dan non fungsional yang diinginkan dari sistem ini.

\section{Perancangan}

Perancangan terdiri dari perancangan arsitektur, perancangan data, perancangan antarmuka dan perancangan prosedural aplikasi.

\section{Implementasi}

Aplikasi diimplementasikan menggunakan PHP pada web server dan basisdata menggunakan MySQL Server.

\section{Pengujian}

Setelah aplikasi selesai dibuat, selanjutnya dilakukan pengujian. Pengujian dilakukan dengan dua cara yaitu pengujian pada komputer standalone dan pengujian pada web server di Jurusan Teknologi Informasi.

\section{a. Pengujian Pada Komputer} Stand Alone

Pengujian ini dimaksudkan untuk mengetahui apakah aplikasi dapat berjalan dengan baik. Pengujian ini dimulai dengan membuka halaman utama (index) kemudian menguji akses pengguna aplikasi dan navigasinya.

\section{b. Pengujian Pada Web Server} Jika pengujian pada komputer stand alone telah selesai selanjutnya dilakukan pengujian dengan menempatkan aplikasi dan basisdata pada web server di Jurusan Teknologi Informasi dan diakses melalui internet.

\section{Perbaikan Aplikasi}

Berdasarkan hasil pengujian, dilakukan jika ditemukan kelemahan-kelemahan aplikasi sehingga belum memenuhi kebutuhan fungsional dan non fungsional yang ditetapkan.

\section{Publikasi}

Jika proses perbaikan telah selesai selanjutnya dilakukan publikasi pada web.

Gambar 4.1 memperlihatkan langkahlangkah pembangunan sistem informasi umpan balik proses belajar mengajar. 


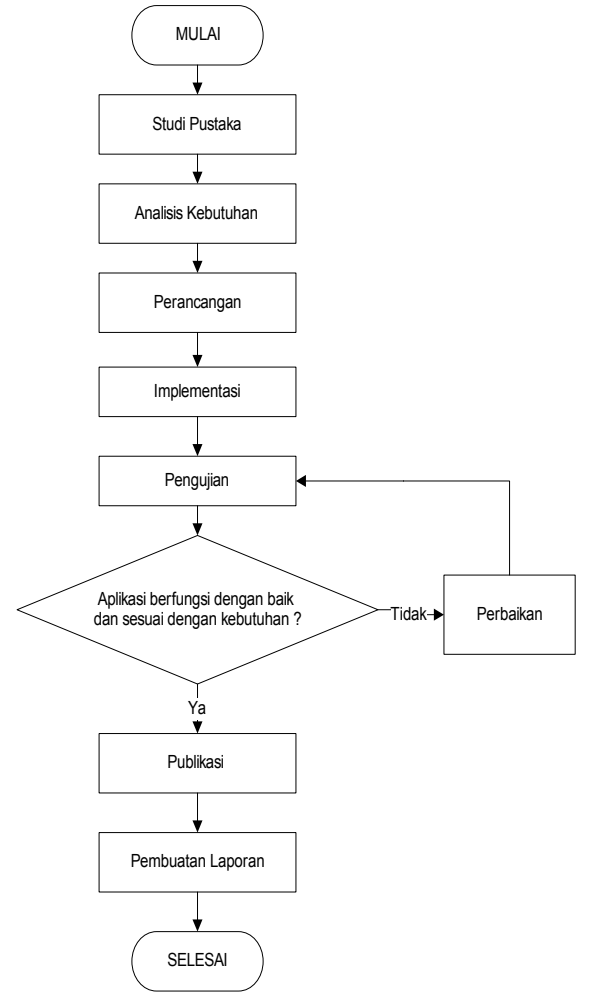

Gambar 4.1.

Tahapan Pembangunan Aplikasi

\section{HASIL}

\section{Gambaran Umum}

Gambaran umum sistem yang dibuat ditunjukkan pada Gambar 5.1.

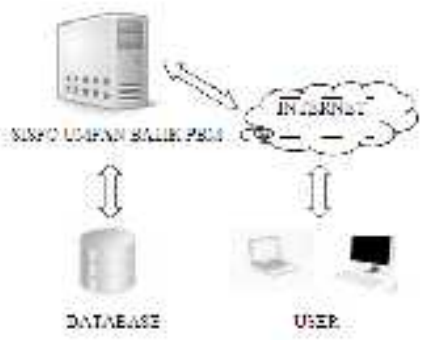

Gambar 5.1.

Gambaran Umum Sistem Informasi

\section{Aliran Sistem Informasi}

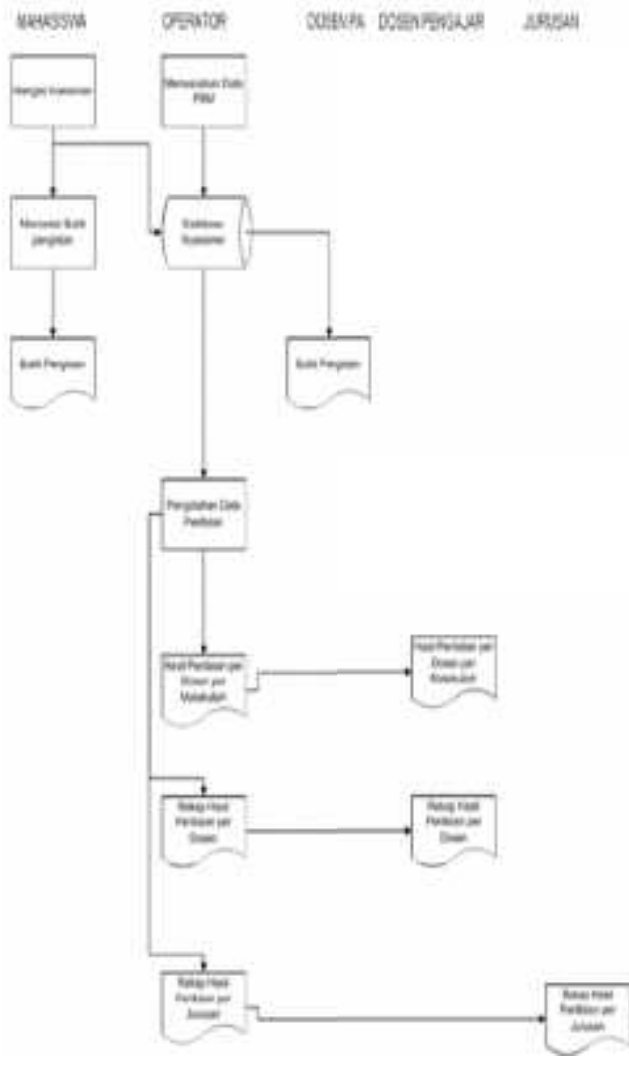

Gambar 5.2. Aliran Sistem Informasi

\section{Perangkat Lunak}

Beberapa perangkat lunak yang digunakan diantaranya adalah :

- Web Server: Apache Server

- Database Management System (DBMS) : MySQL Server

- Bahasa pemrograman :PHP

\section{Basis Data}

Basis data yang digunakan dinamakan dbkuesionerpbm yang terdiri dari tabel Dosen, tabel Kelas, tabel Kelasmahasiswa, tabel Kuesionerpbm, tabel Kurikulum, tabel Mahasiswa, tabel Matakuliah, tabel Mengajar dan tabel User. Spesifikasi masing-masing tabel diperlihatkan pada Gambar 5.3 sampai Gambar 5.10 berikut ini :

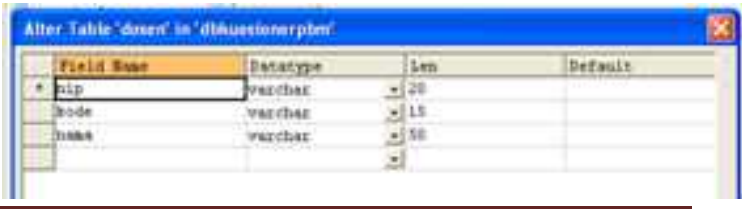


Gambar 5.3 Tabel Dosen

\begin{tabular}{|c|c|c|c|c|}
\hline \multicolumn{5}{|c|}{ 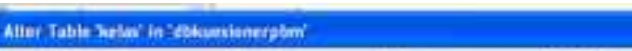 } \\
\hline & neilifren & butavns & Itent & Defrait \\
\hline$\cdot E$ & Inde & Worthas & $=4$ & \\
\hline & netion & yerthar & 512 & \\
\hline & cidepiali & int & 5 & \\
\hline & ungest & int & 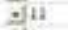 & \\
\hline & vanat & verthat & $=3$ & $2211 / 2012$ \\
\hline 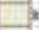 & Enderar & in & 10 & \\
\hline$\theta$ & Dentates & verctiar & s] & cosentz \\
\hline$\square$ & $\mathbf{w}$ & 100 & $\therefore 11$ & \\
\hline 미 & & & 2) & \\
\hline
\end{tabular}

Gambar 5.4 Tabel Kelas

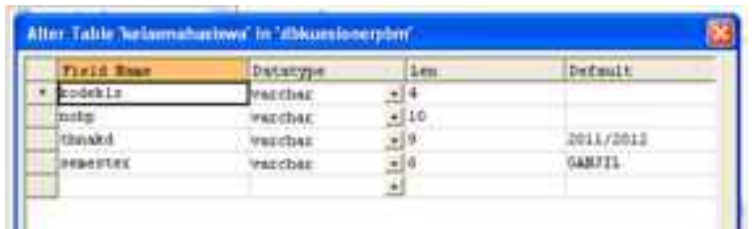

Gambar 5.5 tabel Kelasmahasiswa

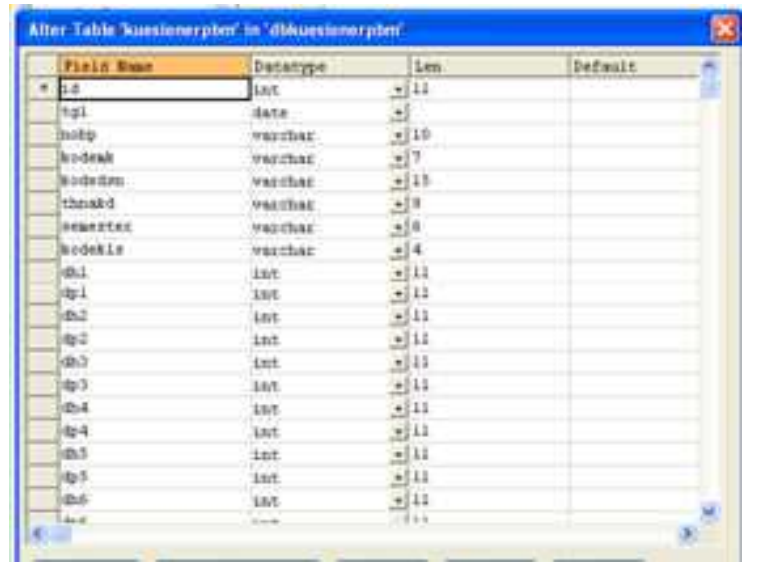

Gambar 5.6 Tabel Kuesionerpbm

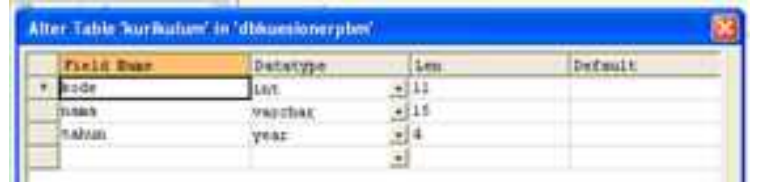

Gambar 5.7 Tabel Kurikulum

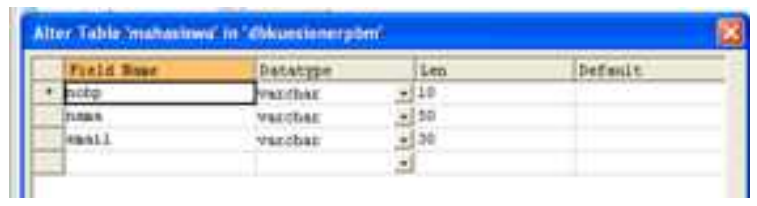

Gambar 5.8 Tabel Mahasiswa

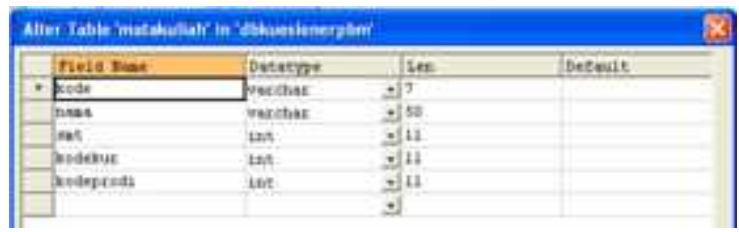

Gambar 5.9 Tabel Matakuliah

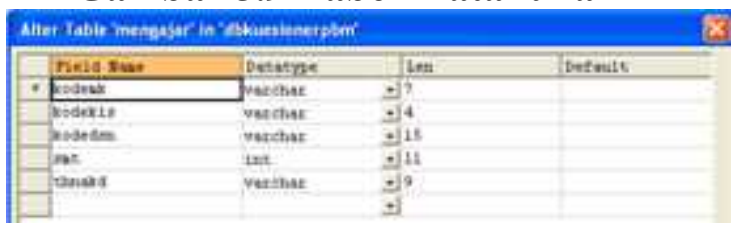

Gambar 5.9 Tabel Mengajar

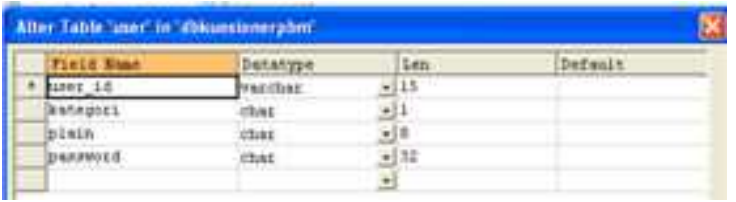

Gambar 5.10 Tabel User

\section{Antarmuka Web}

Gambar 5.11 menampilkan tampilan awal sistem kuesioner online. Gambar 5.12 menampilkan tampilan pemilihan matakuliah untuk pengisian kuesioner. Gambar 5.13 menampilkan tampilan pengisian kuesioner per matakuliah.

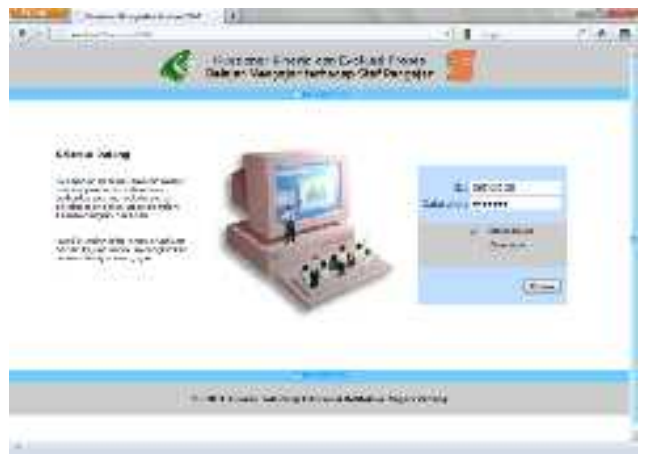

\section{Gambar 5.11 Tampilan Awal Sistem}

Pada tampilan awal sistem ini, user diharuskan untuk memasukkan ID dan kata sandi. ID dan kata sandi ini diberikan oleh dosen Pembimbing Akademik kepada masing-masing kelas.
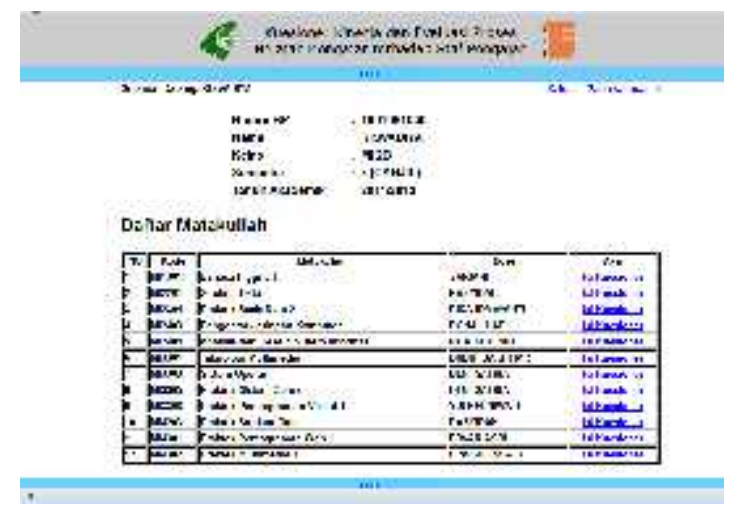

Gambar 5.12 Tampilan Pemilihan Matakuliah Untuk Pengisian Kuesioner 


\section{Kuesioner}

Matakuliah : Bahasa Inggris 3 | Dosen : SARIANI

\section{Petunjuk :}

1. Pilih jawaban yang paling sesua menurut Anda

2. Isilah bagian KEPENTINGAN terlebih dahulu, setelah itu baru isi bagian DIDAPATKAN

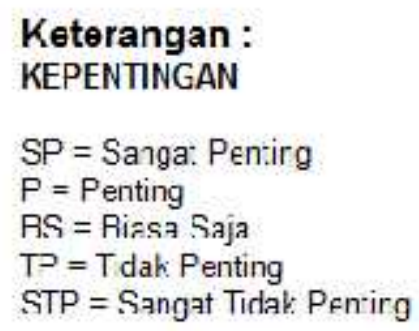

\section{DIDAPATKAN}

$$
\begin{aligned}
& \text { S3 }=\text { Sangat Baik } \\
& D K=\text { Daik } \\
& C P=\text { Cukup } \\
& K G=\text { Kurang } \\
& R 2=\text { Ruruk }
\end{aligned}
$$

\begin{tabular}{|c|c|c|c|c|c|c|c|c|c|c|c|}
\hline \multirow{2}{*}{ NO. } & \multirow{2}{*}{ ELEMEN } & \multicolumn{5}{|c|}{ KEPENIINGAN } & \multicolumn{5}{|c|}{ LIUAPAIKAN } \\
\hline & & SP & $\mathbf{P}$ & BS & TP & STP & SR & $\overline{\mathrm{BK}}$ & C.P & $\overline{K G}$ & $\mathrm{RR}$ \\
\hline & Tangible (Tampilan Fisik) & & & & & & & & & & \\
\hline 1 & $\begin{array}{l}\text { Dosen berpenampilan simpatik, } \\
\text { herpakaian rapi, hersih dan sopan }\end{array}$ & e & e & S & $\theta$ & $\theta$ & (-) & O & (2) & (3) & 0 \\
\hline 2 & $\begin{array}{l}\text { Dosen mengunakan alat bantu dalam } \\
\text { pr oses per kuliahan seperti } L C D, \text { OHP dII }\end{array}$ & e & e. & e & 6 & 6 & Q & (c) & 6 & (1) & (c) \\
\hline 3 & $\begin{array}{l}\text { Dosen mengqunakan buku referens| edIs| } \\
\text { terbaru dalam perkuliahan }\end{array}$ & 8 & 8 & 0 & 0 & 0 & 0 & (9) & 0 & (1) & 0 \\
\hline
\end{tabular}

\section{Gambar 5.13. Tampilan Pengisian Kuesioner}

Kuesioner terdiri dari 29 pertanyaan untuk masing-masing dosen. Jawaban dikelompokkan atas Kepentingan dan Kelompok Yang Didapatkan.

Setelah selesai mengisi kuesioner, mahasiswa mencetak bukti pengisian kuesioner yang disediakan sistem. Tampilannya diperlihatkan pada Gambar 5.14

Pengolahan sistem memberikan hasil penlaian mahasiswa berupa rasio perbandingan antara skor rata-rata untuk kelompok jawaban Kepentingan dan Yang Didapatkan. Rasio ini menunjukkan apakah tingkat kepentingan lebih tinggi daripada yang didapatkan, atau sebaliknya yang didapatkan melebihi tingkat kepentingannya.

Untuk pengguna yang merupakan dosen pengampu matakuliah, disediakan informasi tentang hasil penilaian mahasiswa untuk setiap matakuliah yang diajarkan seperti diperlihatkan pada Gambar 5.15. Selain itu dosen yang bersangkutan juga dapat mengetahui rekap penilaian dari seluruh matakuliah yang diajarkannya dalam suatu semester, seperti diperlihatkan pada gambar 5.16. 


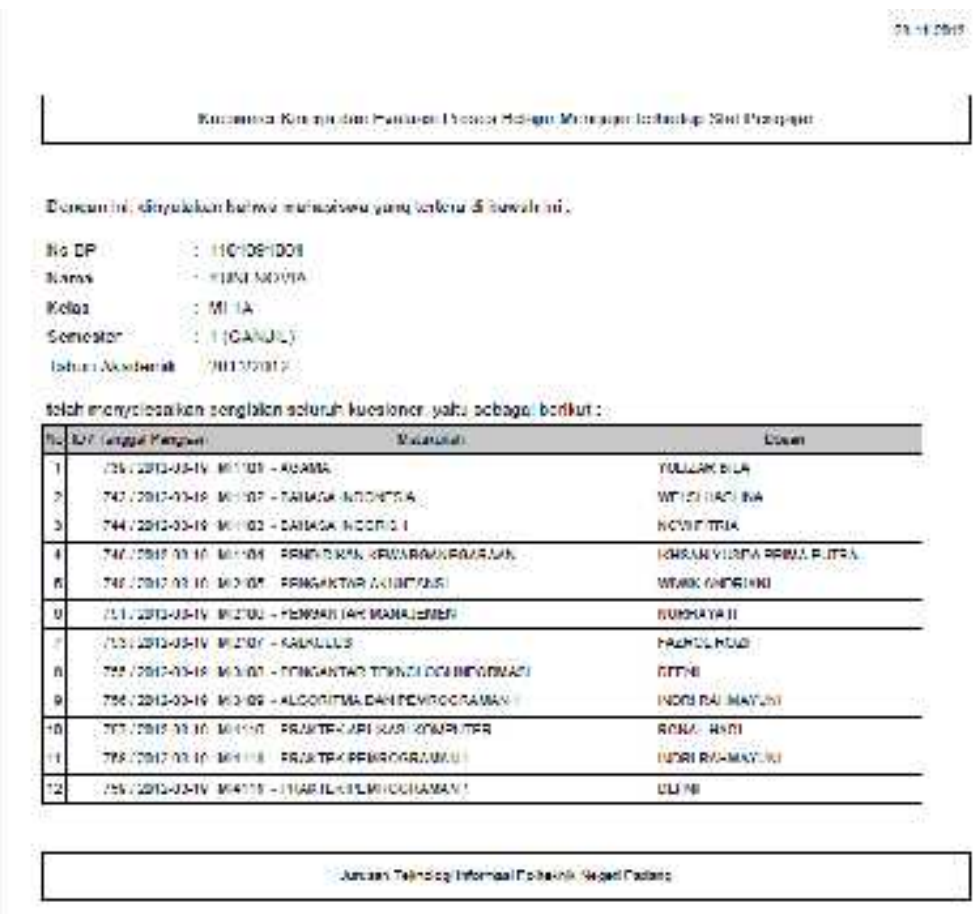

Gambar 5.12 Tampilan Bukti Pengisian Kuesioner

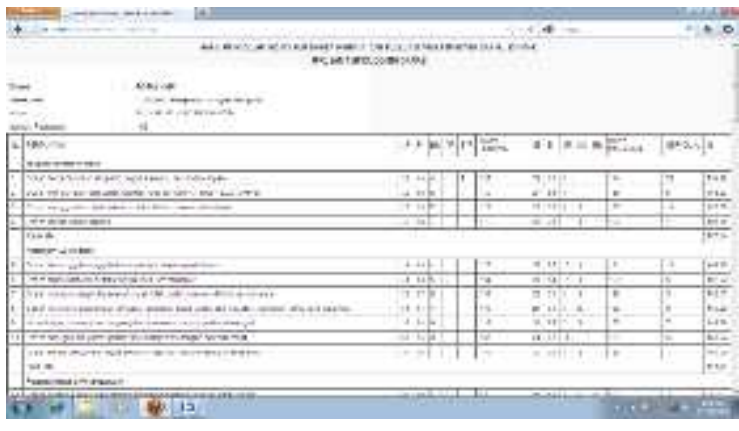

Gambar 5.15.

Tampilan Hasil Pengolahan Kuesioner Per Dosen Per Matakuliah

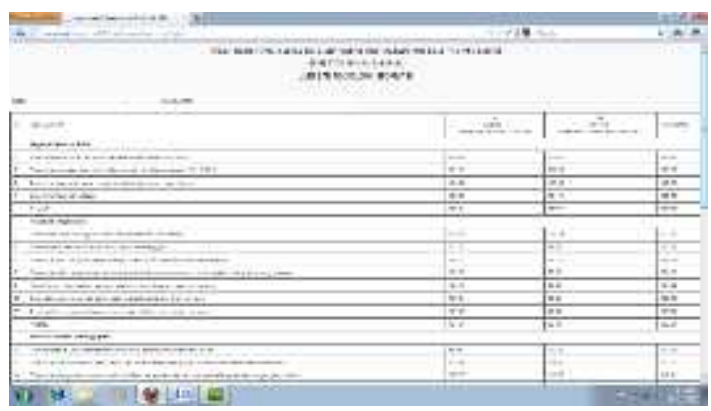

Gambar 5.16.

Tampilan Rekap Hasil Pengolahan Kuesioner Per Dosen

\section{PEMBAHASAN}

Sistem yang dihasilkan merupakan aplikasi yang dijalankan berbasis web, dapat diakses oleh banyak pengguna di waktu yang bersamaan melalui browser di komputer masing-masing dengan mengakses alamat yang ditentukan. Pengguna sistem ini terdiri dari mahasiswa, operator, administrator, pimpinan dan staf pengajar. Sistem ini dapat menerima input kuesioner dari seluruh mahasiswa setiap matakuliah, dapat mengolah data kuesioner, dapat menampilkan rekap hasil penilaian staf pengajar setiap matakuliah kepada pimpinan di tingkat program studi dan jurusan serta dapat menampilkan rekap hasil penilaian per matakuliah kepada staf pengajar pengampu matakuliah yang bersangkutan. Format dan cara pengolahan kuesioner mengikuti apa yang telah ditetapkan SPM PNP. Sistem ini dibangun menggunakan bahasa pemrograman $P H P$ dan basisdata MySQL Server.

Kelebihan sistem ini adalah dapat menghemat kertas dan tempat 
penyimpanan fisik. Selain itu, lebih praktis dalam pengisiannya karena dengan hanya login ke aplikasi maka tidak perlu memasukkan data profil pengisi dan dalam pengisian kuesionernya cukup mengklik pilihan yang disediakan. Pengisian kuesioner menggunakan sistem ini langsung diinputkan oleh mahasiswa tanpa membutuhkan tenaga kerja khusus, dan memakan waktu yang relatif singkat yaitu sekitar 15 menit per mahasiswa untuk seluruh matakuliah pada semester tersebut. Pengolahannya juga tidak membutuhkan tenaga kerja khusus, hasil pengolahan dapat dapat diakses oleh pihak-pihak yang berkepentingan. Dengan tersedianya sistem ini secara online maka mahasiswa dan pengguna lainnya dapat mengakses kapanpun dan dimanapun. Sedangkan keterbatasannya adalah hanya terbatas untuk penilaian staf pengajar saja, Untuk ke depannya dapat dikembangkan untuk kuesionerkuesioner lain dan diintegrasikan.

\section{SIMPULAN}

1. Sistem Informasi Umpan Balik Proses Belajar Mengajar terhadap staf pengajar ini merupakan aplikasi berbasis web yang telah dapat digunakan untuk pengisian kuesioner penilaian oleh mahasiswa terhadap proses belajar mengajar yang diberikan oleh staf pengajar, dan dapat diakses secara online oleh banyak pengguna pada waktu yang bersamaan.

2. Sistem ini dapat memudahkan, menghemat waktu dan mengurangi tingkat kesalahan dalam memasukkan dan mengolah data kuesioner.

3. Sistem ini dapat menyediakan informasi tentang hasil analisis umpan balik / kuesioner, kepada pimpinan untuk kemudian dapat ditindaklanjuti dan kepada staf pengajar yang menjadi objek penilaian untuk dijadikan bahan koreksi jika terdapat kekurangankekurangan dalam mengajar sehingga mutu kegiatan belajar mengajar dapat ditingkatkan.

4. Kelebihan sistem ini adalah dapat menghemat kertas dan tempat penyimpanan fisik, pengolahannya tidak membutuhkan tenaga kerja khusus dan hasil pengolahannya langsung dapat diakses oleh pihakpihak yang berkepentingan.

5. Sedangkan keterbatasannya adalah hanya terbatas untuk penilaian staf pengajar saja, hasil pengolahan merupakan rasio penilaian dan belum menghasilkan indeks prestasi dosen.

\section{SARAN}

1. Sistem ini dapat dikembangkan untuk menghasilkan indeks prestasi dosen (IPD).

2. Karena masih terbatas untuk penilaian staf pengajar saja, maka untuk ke depannya dapat dikembangkan untuk kuesionerkuesioner lain dan diintegrasikan.

\section{DAFTAR PUSTAKA}

Arifin, Zainal, 2011, Evaluasi Pembelajaran, Cetakan ke-3. PT Remaja Rosdakarya, Bandung.

Hartini, Sri dkk, 2010. Sistem Evaluasi Kinerja Institusi Pendidikan dengan Questionnaire Berbasis Web (Studi Kasus : Teknik Industri Undip), SNPPTI 2010 ISSN: 20862156 hal: $168-172$.

Heryandi, Andri, 2012, Pembangunan Sistem Informasi Pengisian Survey Evaluasi Perkuliahan 
Online di Universitas Komputer Indonesia, Jurnal Ilmiah Komputer dan Informatika (KOMPUTA), Volume. I Nomor. 2, Bulan Oktober 2012 - ISSN :20899033 hal: $85-88$.

Jogianto, H.M, 2005, Analisa dan Disain Sistem Informasi, Penerbit Andi Offset, Yogyakarta.

Kristanto, Andri, 2003, Perancangan Sistem Informasi dan Aplikasinya, Penerbit Gaya Media, Yogyakarta.

Kadir, Abdul, 2009, From Zero To A Pro, Membuat Aplikasi Web dengan PHP + Database $M y S Q L, \quad$ Penerbit Andi Offset, Yogyakarta.

Kadir. Abdul, 2008, Belajar Database Menggunakan MySQL, Andi Offset. 
ISSN :2085-6989 